portion are by the director of the Institute, Dr. G. E. R. Deacon, and these serve an excellent purpose in popularizing the subject. It is very unlikely that anyone interested in the work of the Institute would have easy access to the majority of the journals used by the staff, and so the issue of collected reprints is specially welcome.

\section{Oundle School Natural History Society}

THE annual report for 1953 of the Oundle School Natural History Society, edited by B. W. H. Coulson and I. F. Thomas, has recently been published. It is disappointing to read that "Too much is still left to a few keen members and ... how few members help by providing records". This remark does not necessarily indicate a lack of interest in practical natural history, for all too often the most enthusiastic fail to record their work, which is a pity from several points of view. Three lectures, a series of short talks and a conversazione were some of the indoor activities of the Society during the year, and Oundle School took part in the annual exhibition of the Association of School Natural History Societies at the British Museum (Natural History) on November 7. Among the reports of groups are : mammals, in which a study of bats in Oundle is suggested; birds, recording rarities, phenology and ringing; fish-all coarse, freshwater species; Crustacea; Arachnida ; Lepidoptera ; Ephemeroptera ; Hemip. tera; Diptera; Annelida, including physiological experiments on leeches; flowering plants, including phenology, new species and ecology ; fungi. Notes are also included in the report on the biology of a lake and a fen together with records of various animals kept in the laboratory. Oundle School is clearly taking advantage of its excellent position for field natural history, and is not lacking in enthusiasm. It is to be hoped, therefore, that the members of its Natural History Society will heed the remarks of the editors of the annual report concerning lack of written records, for this is very important.

\section{Flora of the Belgian Congo}

Tre fourth volume of the "Flore du Congo Belge et du Ruanda-Urundi" (P.ubl. Inst. Nat. pour l'Étude Agron. du Congo Belge, pp. 314, with map and line drawings; Brussels, 1953) deals with the Spermatophytes, Papilionaceae (Part I), of this rich and varied floristic region. Accounts of the tribes Sophoreae, Genisteae, Trifolieae and Loteae, each contributed by a different author, are here given; the other tribes of this order will be desit with in two subsequent volumes. Analytical keys are provided for the tribes, genera and species; the genera and species being described in detail (in French) with notes on their distribution and habitat and occasional illustrations. The publishers are to be congratulated on the clarity of the arrangement and text.

\section{Arid Zone Research}

The general conference of Unesco at its sixth session held in Paris in 1951 authorized the DirectorGeneral "to collect and disseminate information on research being carried out on problems of the Arid Zone and on the organizations, scientists and engineers engaged in such research". As a result, the secretariat undertook a survey among the member States of the institutions primarily devoted to scientific and technical research on problems of arid and semi-arid areas. A directory has now been published which gives detailed information about these institutions. The ninety institutions listed are located in sixteen countries and seven dependent. territories spread over the five continents of the world. Copies of the directory can be obtained from H.M.S.O., price $8 s$. $6 d$.

\section{British Institution of Radio Engineers : Convention in Oxford}

THE third post-war convention of the British Institution of Radio Engineers will be on industrial electronies and will be held in the University of Oxford during July 8-12. The Institution's Clerk Maxwell Memorial Lecture will be delivered in the Clarendon Laboratory, Oxford, by Sir John Cockcroft, director of research, Atomic Energy Research Establishment, Harwell, on the evening of July 8. More than thirty papers will be presented at the six sessions, which will be as follows: industrial applications of electronic computors; industrial applications of $\mathrm{X}$-rays and sonics; nucleonic instrumentation and application; electronic sensing devices (transducers); process control ; and industrial aids to production. The registration fee for members of the Institution is $10 s$. $6 d$. a day or $£ 111 s$. $6 d$. for the whole convention (for non-

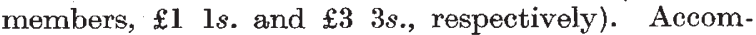
modation may be reserved at Christ Church, Oxford. A detailed programme and reservation forms can be obtained from the Secretary of the Institution, 9 Bedford Square, London, W.C.I.

\section{South-Eastern Union of Scientific Societies: Con- gress in Maidstone}

THE fifty-ninth annual congress of the SouthEastern Union of Scientific Societies will be held in the Museum and Art Gallery, St. Faith Street, Maidstone, during June 10-13. After his induction on June 11, the new president of the Union, Dr. Glyn Daniel, will give an address on "The Art of Megalith Builders". "The Union is divided into archæology, botany, geology and zoology sections, and the individual presidents of the sections and the titles of their addresses will be as follows: Archoeology, F. C. Elliston Erwood, on the present state of monastic archæology in Kent; Botany, J. E. Lousley, on the amateur botanist in 1954; Geology, H. E. P. Spencer, on the Pleistocene period and work for the amateur geologist; Zoology, Dr. G. E. Newell, on animal zones of the North Kent coast. Further information can be obtained from the honorary local secretary for the meeting, L. R. A. Grove, Museum and Art Gallery, St. Faith Street, Maidstone.

\section{Physical Society: Summer Meeting}

THE annual summer meeting of the Physical Society will take the form this year of three open lectures (no ticket of admission being necessary), given in connexion with the General Assembly of the International Union of Pure and Applied Physics, and will be held at the Royal Institution, 21 Albemarle Street, London, W.1, on July 7 and 9 at 4.30 p.m. and on July 13 at 2.30 p.m. The lectures will be as follows: fields and particles, by Prof. J. A. Wheeler (Palmer Physical Laboratory, Princeton University); the European Organization for Nuclear Research, by Prof. E. Amaldi (Guglielmo Marconi Institute of Physics, Rome) ; and microwave experiments in the physics of solids, by Prof. C. Kittel (University of California, Berkeley). 